\title{
Preparation of Activated Carbon from Waste Penicillin Mycelium
}

\author{
Mi-Mi CHEN ${ }^{1, a}$,Tie-Lin Fan ${ }^{1, b}$ and Feng-Qing ZHAO ${ }^{1,2, c^{*}}$ \\ ${ }^{1}$ Department of Chemical Engineering, Hebei University of Science \& Technology, Shijiazhuang, \\ 050018, China \\ ${ }^{2}$ Hebei Engineering Research Center of Pharmaceutical and Chemical Engineering,Shijiazhuang \\ 050018, China \\ a785498424@qq.com, b441053019@qq.com,, ${ }^{\mathrm{C}}$ Zhaofq3366@126.com \\ ${ }^{*}$ Corresponding author
}

Keywords: Mycelium, Gypsum, Setting retarder, Activated carbon.

\begin{abstract}
We proposed a clean and safe method of preparation of activated carbon from waste penicillin mycelium by first soaking it in aqueous alkaline solution, to remove protein by filtration. Then the protein-free filter cake can be used to produce activated carbon without $\mathrm{NO}_{\mathrm{X}}$ emission. The optimal conditions for the preparation of activated carbon are achieved: activation time in $\mathrm{ZnCl}_{2}$ solution (20 wt\%) $1.5 \mathrm{hrs}$; carbonization time $1 \mathrm{hr}$; carbonization temperature $300^{\circ} \mathrm{C}$; and liquid-solid ratio 2.0. Not only will this process prevent the environmental impact of current treatments, as incineration, stockpile or directly producing activated carbon, as well as the risks in antibiotics abuse when used in animal feed.
\end{abstract}

\section{Introduction}

Waste penicillin mycelium (WPM) comes from the process of penicillin production (at the end of penicillin fermentation), which was once used for poultry feed or treated by incineration before [1]. The former might result in antibiotic abuses and has been prohibited recently in China and other countries [2]. The later can produce $\mathrm{SO}_{\mathrm{X}}$ and $\mathrm{NO}_{\mathrm{X}}$, which would cause serious pollution to the environment. It has been found that WPM contains a large amount of proteins, fiber, enzymes, which can be used to produce some valuable products, such as chitosan, ergosterol and activated carbon $[3,4,5,6,7]$. It is pity that the proteins in WPM were underutilized in all these approaches. In our former experiments, we found that WPM contains about $20 \%$ proteins, which could be used to extend the setting time of hemihydrates gypsum after modification [2]. But the remaining filter cake has not been effectively solved.

The purpose of this work was to prepare activated carbon from WPM without $\mathrm{NO}_{\mathrm{X}}$ emission, to obtain a safe and environment friendly process. Not only will this process decrease the stockpile of waste material but also reduce the impact of current treatments on the environment as well as the problems associated with disposing waste materials to landfill sites.

\section{Materials and Methods}

\section{Raw Materials}

The WPM used was from Huabei Pharmaceutical Co. Ltd. The composition is listed in Table 1.

Table 1. Elemental composition of waste penicillin mycelium.

\begin{tabular}{llllll}
\hline Element & C & H & N & S & O \\
\hline Composition (wt\%) & 44.08 & 6.26 & 9.45 & 1.44 & 32.84 \\
\hline
\end{tabular}

Both caustic soda and zinc chloride are bought on the market. Sodium polyphosphate was offered by the Aladdin Co. Ltd. Caustic soda was used to adjust the $\mathrm{pH}$ value of soaking process, which is available on the market. 


\section{Methods}

Waste penicillin mycelium was dried and crushed into powders of the specific area of $300-350 \mathrm{~m}^{2} / \mathrm{kg}$, then soaked in aqueous solution at certain $\mathrm{pH}$ value and temperature. After soaking, the mixture was separated by filtration to obtain WPM retarder, the filtrate. The filter cake is used to produce activated carbon by carbonation, pickling, washing, drying and crushing process. See Fig. 1.The adsorption capacity test of activated carbon was performed as per GB/T12496.8-1999 (Test methods of wooden activated carbon-Determination of iodine number).

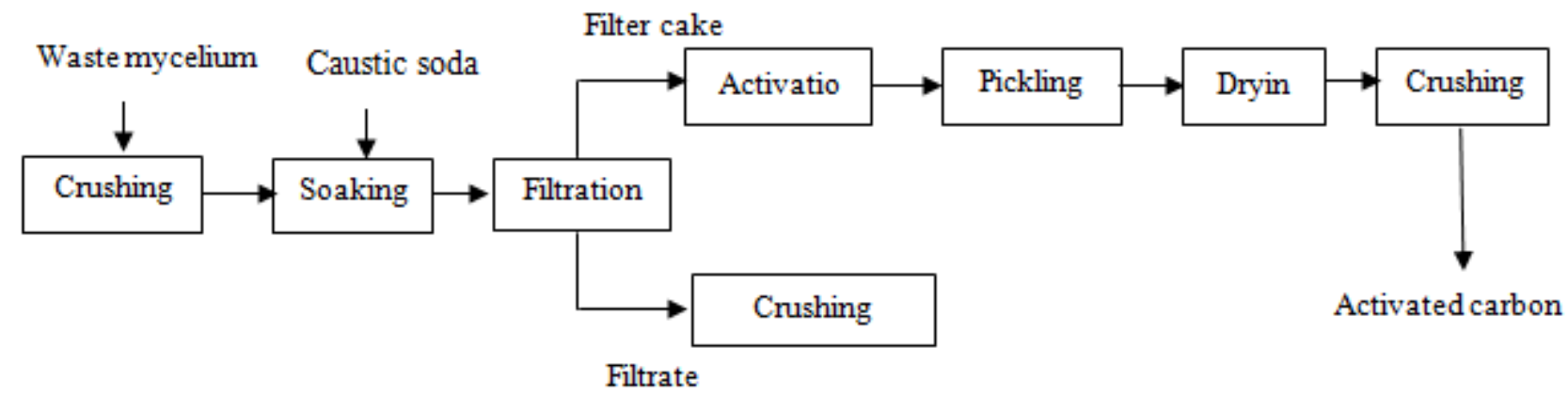

Fig. 1. Process of WPM retarder synthesis from waste mycelium.

\section{Results and Discussion}

Because most protein was extracted, the filter cake from preparation of WPM retarder can be treated by incineration with little $\mathrm{NO}_{\mathrm{X}}$ emission.

The major factors influencing the activated carbon from the filter cake are carbonation time, temperature, concentration of activator, dipping time and liquid-solid ratio respectively based on the trial test results. Considering iodine number of activated carbon reflects its adsorption performance, the effects of the five factors on the iodine number of activated carbon were investigated. The results are shown in Fig. 2-6.

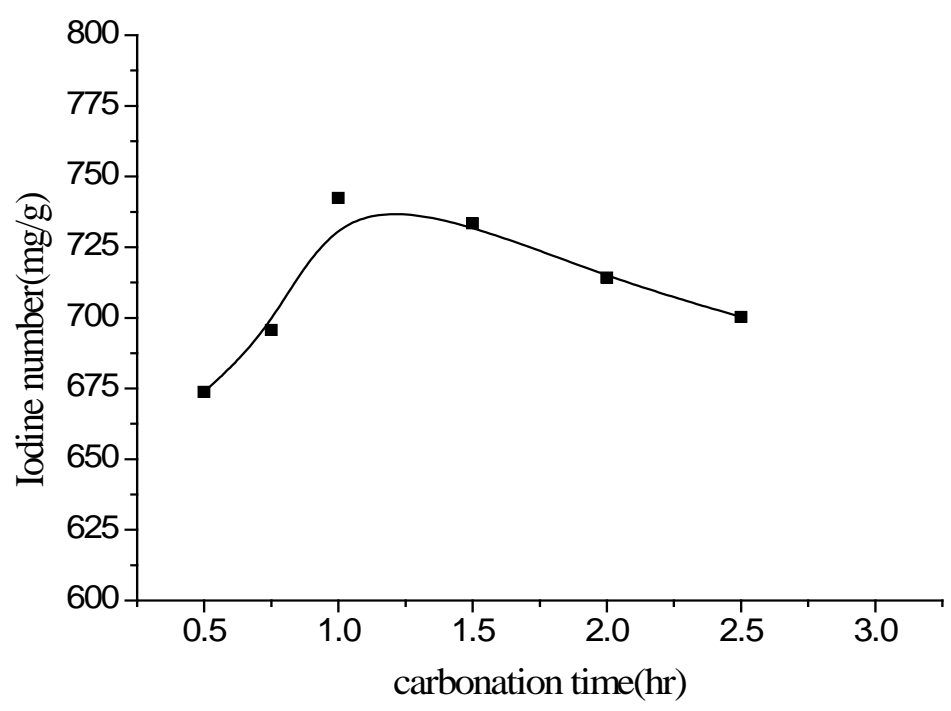

Fig. 2. Effect of carbonation time on the iodine number of activated carbon

From Fig. 2, we can see that with the increase in carbonization time, the iodine number of the prepared activated carbon increased. The peak of iodine number appears at the carbonation time of $1 \mathrm{hr}$, then declined thereafter. It may be because the generated part of the microporous structure is destroyed, which resulted in increased aperture, adsorption performance degradation. 


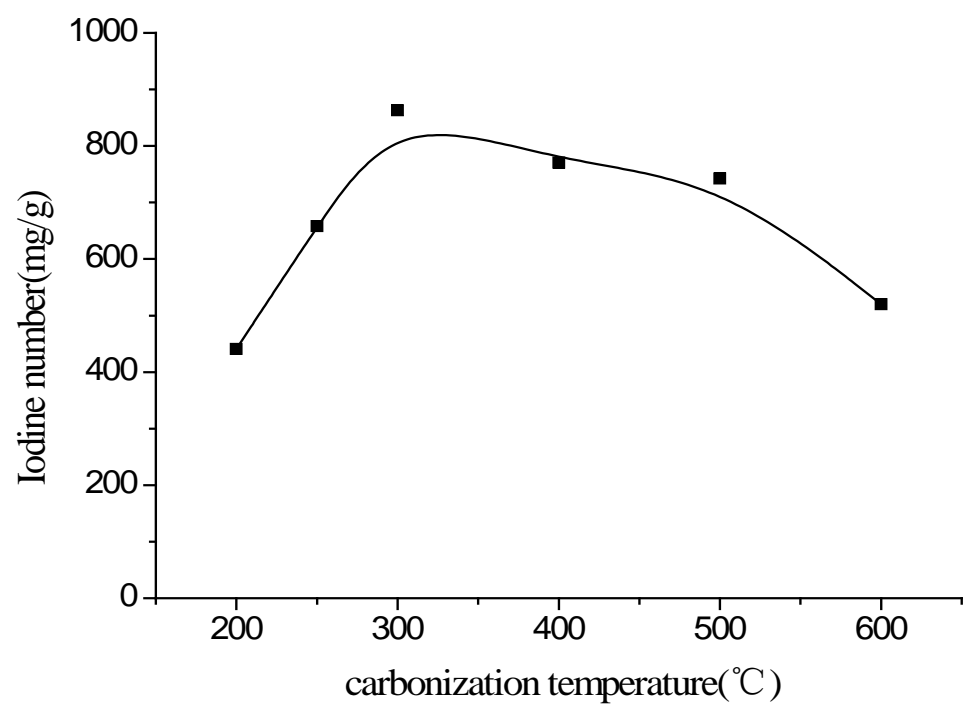

Fig. 3. Effect of carbonation temperature on the iodine number of activated carbon

It can be seen in Fig. 3 that the carbonization temperature has significant effect on the iodine number of the prepared activated carbon. With the increase in temperature, the iodine number increased gradually. When the temperature increases to $300^{\circ} \mathrm{C}$, the iodine number reaches maximum, $836.2 \mathrm{mg} / \mathrm{g}$. However, as temperatures rise further, a large number of microporous structure is destroyed, the iodine number of activated carbon dropped significantly.

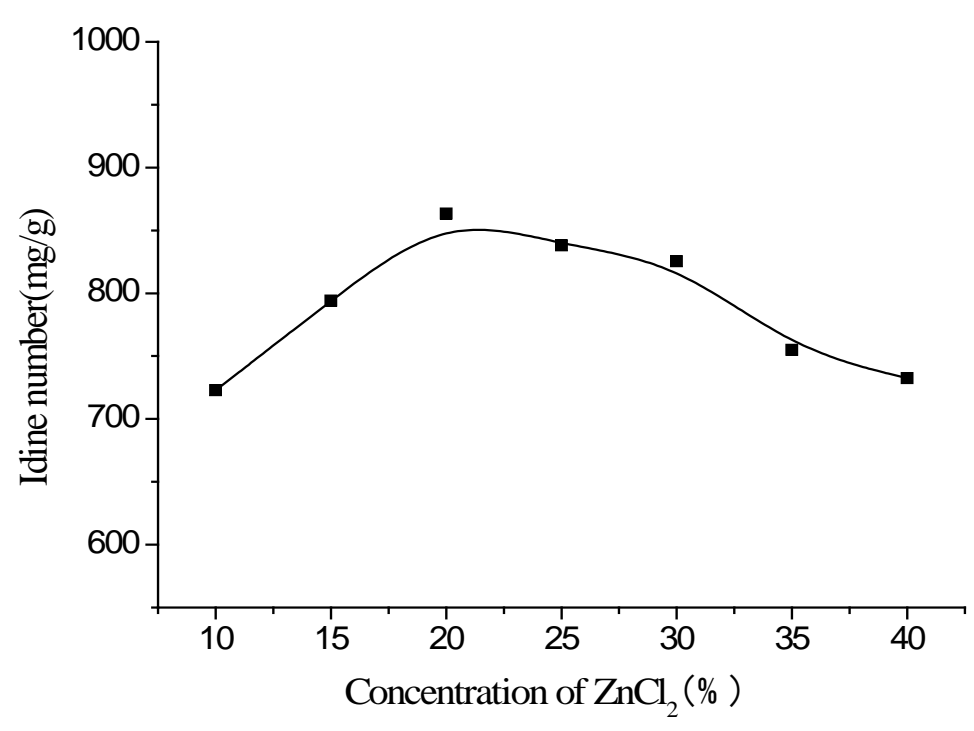

Fig. 4. Effect of concentration of activator on the iodine number of activated carbon

Fig. 4 shows that the iodine number of the prepared activated carbon increases with the increase of the concentration of the activator. When the concentration exceeds $20 \%$, the iodine number gradually decreased. In the present of activator, the carbon containing compounds in filter cake undergoes dehydration, condensation, swelling, forming a non-volatile condensed carbon with porous structure. In a certain range, the higher the concentration of the activator, the more significant the dehydration condensation effect of the carbon containing compounds and the better the pore structure is developed. But when the concentration of activator exceeds $20 \%$, the excessive $\mathrm{ZnCl}_{2}$ tends to plug the pores, which hinders further dehydration condensation, resulting in 
difficulty of the subsequent cleaning work, and increases the production cost. Therefore, the appropriate concentration of the activator is $20 \%$.

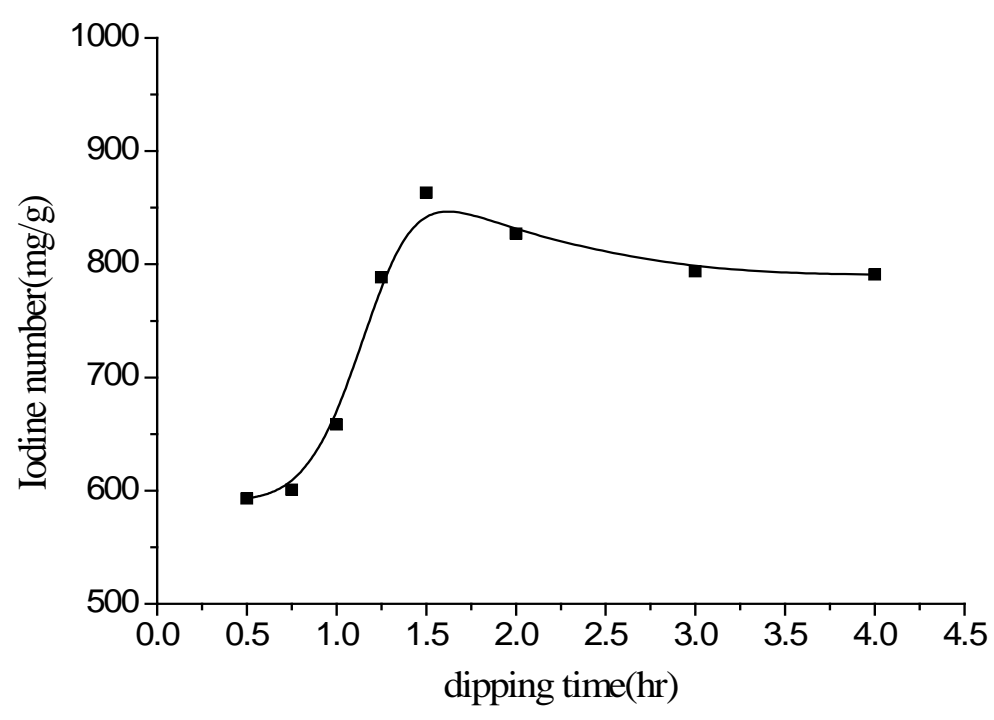

Fig.5. Effects of the dipping time on the iodine number of activated carbon.

As it is shown in Fig. 5, the dipping time of the filter cake in activator has a certain influence on the iodine number of activated carbon. With the increase of dipping time, the iodine number of activated carbon increases significantly when the dipping time is less than $1.5 \mathrm{hrs}$. And the iodine number reaches the maximum, $863.2 \mathrm{mg} / \mathrm{g}$, around $1.5 \mathrm{hrs}$, then the iodine number of activated carbon basically remains a constant thereafter. So the dipping time of $1.5 \mathrm{hrs}$ is better.

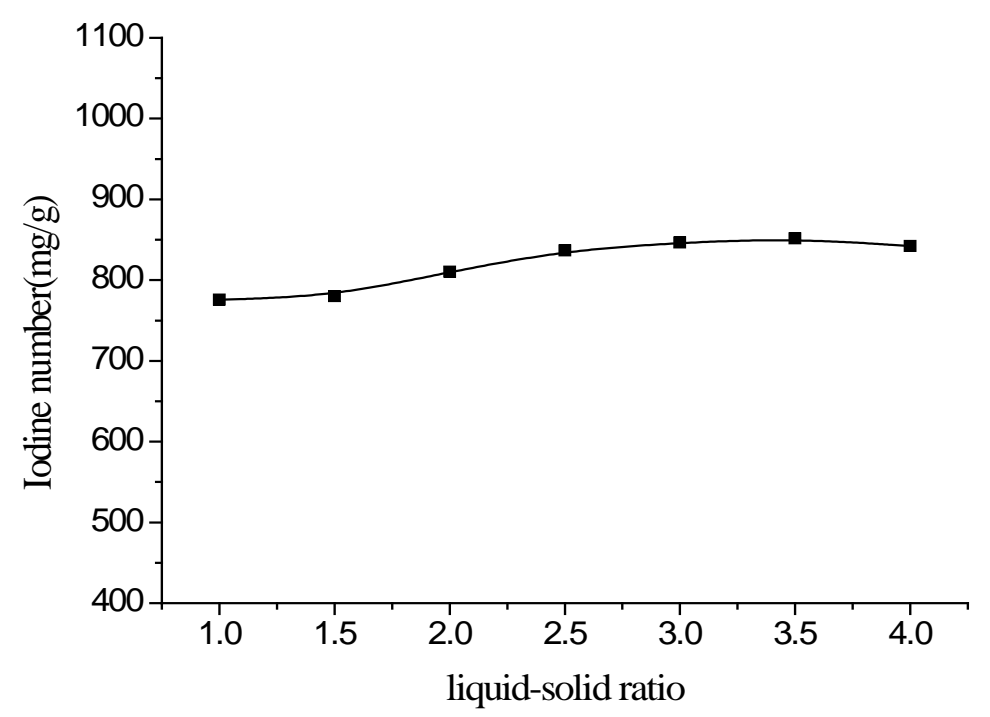

Fig.6. Effects of liquid-solid ratio on the iodine number of activated carbon.

It is can be seen from Fig. 6, when the liquid-solid radio is relatively low, the filer cake could not be fully infiltrates, which causes uneven activation of the filer cake and relatively lower iodine number. With the increase of liquid-solid ratio, the iodine number of activated carbon has a slight increase. Overall, the effects of liquid-solid ratio on the iodine number of activated carbon are not significant. Considering cost, the liquid-solid ratio is fixed at 2.0. 
The optimal conditions for the preparation of activated carbon was thus obtained: carbonization time $1 \mathrm{hr}$; carbonization temperature $300^{\circ} \mathrm{C}$; activation time in $\mathrm{ZnCl}_{2}$ (20 wt\%) $1.5 \mathrm{hrs}$; and liquid-solid ratio 2.0. The activated carbon produced meets the requirements of general industrial applications, whose iodine number $674 \mathrm{mg} / \mathrm{g}$, methylene blue adsorption $14.27 \mathrm{mg} / \mathrm{g}$ and specific surface area $179 \mathrm{~m}^{2} / \mathrm{g}$. See Table 2 .

Table 2. Main specifications of activated carbon from filter cake.

\begin{tabular}{lllll}
\hline $\begin{array}{l}\text { Technical } \\
\text { index }\end{array}$ & $\begin{array}{l}\text { Iodine number } \\
\left(\mathrm{mg} \cdot \mathrm{g}^{-1}\right)\end{array}$ & $\begin{array}{l}\text { Methylene blue adsorption } \\
\left(\mathrm{mg} \cdot \mathrm{g}^{-1}\right)\end{array}$ & $\begin{array}{l}\text { Specific surface area } \\
\left(\mathrm{m}^{2} \cdot \mathrm{g}^{-1}\right)\end{array}$ & $\begin{array}{l}\text { Yield } \\
(\mathrm{wt} \%)\end{array}$ \\
\hline $\begin{array}{l}\text { Measured } \\
\text { value }\end{array}$ & 674 & 14.27 & 179 & 23 \\
\hline
\end{tabular}

\section{Summary}

Waste penicillin mycelium (WPM) is a harmful solid waste in pharmaceutical production that has plagued the industry for many years. Current measures either exists safety risks or pose environmental pollution when used for poultry feed or treated by incineration. In this study, we soaked WPM in aqueous alkaline solution, to remove the protein hydrolysate. The protein-free filter cake from the retarder process was used to produce activated carbon, while the washing water can be recycled to hydrolysis process, forming a clean production process. Several factors in the preparation of activated carbon were investigated. The optimal conditions for the preparation of activated carbon are achieved: activation time in $\mathrm{ZnCl}_{2}$ solution (20 wt\%) $1.5 \mathrm{hrs}$; carbonization time $1 \mathrm{hr}$; carbonization temperature $300{ }^{\circ} \mathrm{C}$; and liquid-solid ratio 2.0. The activated carbon produced can meet the requirements of general industrial applications. Not only will this process decrease the impact of current treatments, as incineration or stockpile, on the environment as well as overuse of antibiotics when used in animal feed. Thus a clean and safe method of treating waste penicillin mycelium was obtained, and it has some reference value for the treatment of the waste mycelia of other sources.

\section{References}

[1] V. M. Doctor, L. Ker, Penicillium mycelium waste as protein supplement in animals, Appl. Envir. Microbiol. 16 (1968) 1723-1726.

[2] X. Q. Ren, F. Q. Zhao, Waste Mycelium Processing and Resource Utilization. Advanced Materials Research. 746 (2013) 58-61.

[3] C. F. Wang, Extraction of chitosan from waste mycelium (In Chinese), China Brewing. 10 (2009) 124-126.

[4] J. H. Peng, J. X. Zhang, M. F. Chen, L. Wu, J. D. Qu, Influence of macromolecule-type retarders on the hydration process of building gypsum and its retarding mechanism (In Chinese). Journal of the Chinese ceramic society. 36 (2008) 896-900.

[5] Q. Han, H. J. Su, Comparison of cell wall broken in the research of high value utilization of mycelium residue (In Cinese). Environmental Science \& Technology. 34 (2011) 144-147.

[6] Q. Q. Feng, B. Wu, Y. Z. Li, B. S Tian, X. Y Zhong, Study on building gypsum retarder of bone glue protein (In Chinese). New Building Materials. 6 (2007) 5-7.

[7] B Guo, L Gong, E Duan, R Liu, A Ren, J Han, W Zhao. Characteristics of penicillin bacterial residue. Journal of the Air \& Waste Management Association. 62(2012)485-488. 